\title{
NUTRITION OF PRETERM INFANTS AND RAW BREAST MILK- ACQUIRED CYTOMEGALOVIRUS INFECTION: FRENCH NATIONAL AUDIT OF CLINICAL PRACTICES AND DIAGNOSTIC APPROACH.
}

\author{
Anne-Aurelie LOPESa, MD, Valerie CHAMPIONb, MD, Delphine MITANCHEZb, MD, PhD. \\ a Pediatric Emergency Department, AP-HP, Robert Debre Hospital, Paris, France, \\ b Neonatology Department, AP-HP, Armand Trousseau Hospital, Paris, France.
}

\begin{abstract}
Introduction: Raw breast milk is the optimal nutrition for infants, but it is also the primary cause of acquired cytomegalovirus (CMV) infection [1]. In the 1990s to 2000s, studies demonstrated that, in children born before a corrected age of 32 weeks or below a weight of $1500 \mathrm{~g}$, the CMV transmission rate was over $50 \%$ in the first three months of life [2]. Moreover, $50 \%$ of preterm infants had symptomatic infections, and $15 \%$ of these infections were severe with a low C-reactive protein level and were called "sepsis-like" [1]. Thus, many countries have chosen to contraindicate to feed raw breast milk preterm infants from CMV-positive mothers before a corrected age of 32 weeks or under a weight of $1500 \mathrm{~g}$ [3-4]. However, since the 2010s this contraindication was more and more discussed [5]. In France, national recommendations have not been updated since 2005 [6] whereas several cases of postnatal breast milk-acquired before a corrected age of 32 weeks have been published by French neonatal units [7-10].
\end{abstract}

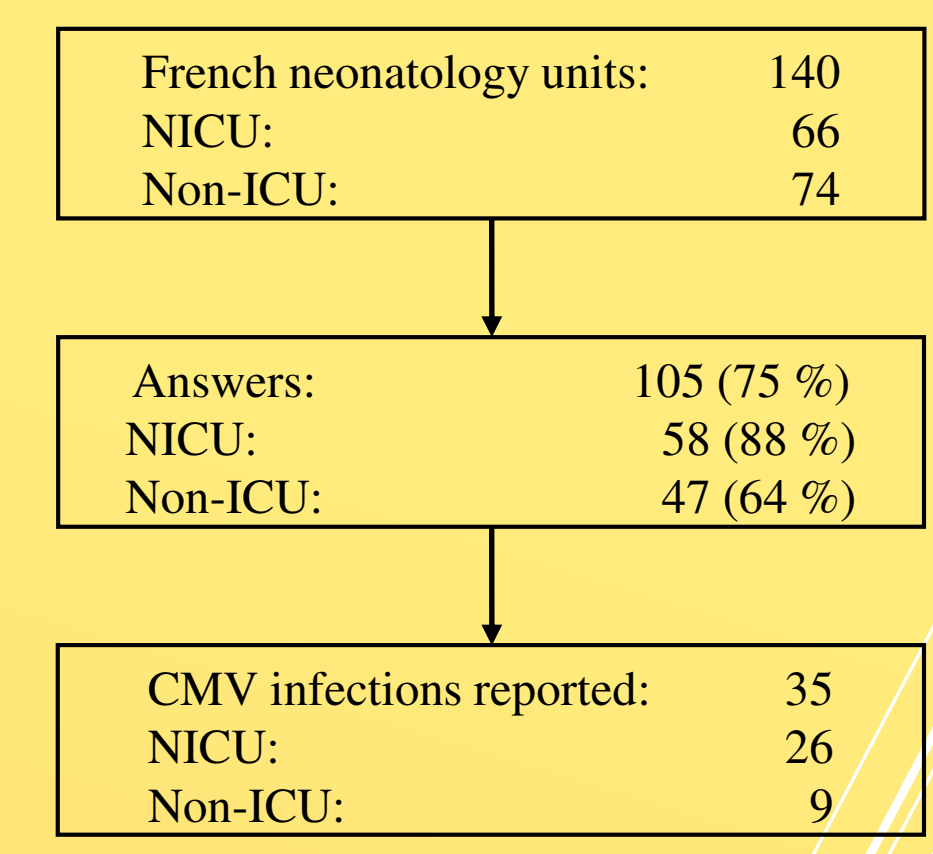

Methods: An national audit of the French current clinical practices regarding breast milk nutrition in preterm infants was carried out using a questionnaire sent to all neonatal care units. Concurrently, a first national census of diagnosed postnatal milkacquired CMV infections was carried out, and the validity of the diagnosis was analysed using hospitalisation reports. The reported cases have been classified as "proven", "highly probable", "probable" or "unlikely" breast milk-acquired infections.

Results: Seventy-five per cent of the neonatal units responded. The main results about breast milk nutrition are displayed graphically. Regarding mothers' raw breast milk nutrition in preterm infants, $24 \% \mathrm{f}$ the units complied with the French recommendations, $20 \%$ contraindicated raw breast milk to all infants before 32 weeks regardless of the mothers' CMV-status whereas $25 \%$ fed all preterm infants unconditionally with raw breast milk. Thirty-five cases of infants with milk-acquired CMV infections have been reported. On the 17 hospitalisation reports obtained, the diagnosis was undeniable for five patients. Based on their history, two patients probably had congenital infections. The characteristics of the 15 other cases and the missing information in the diagnosis approach are described below.

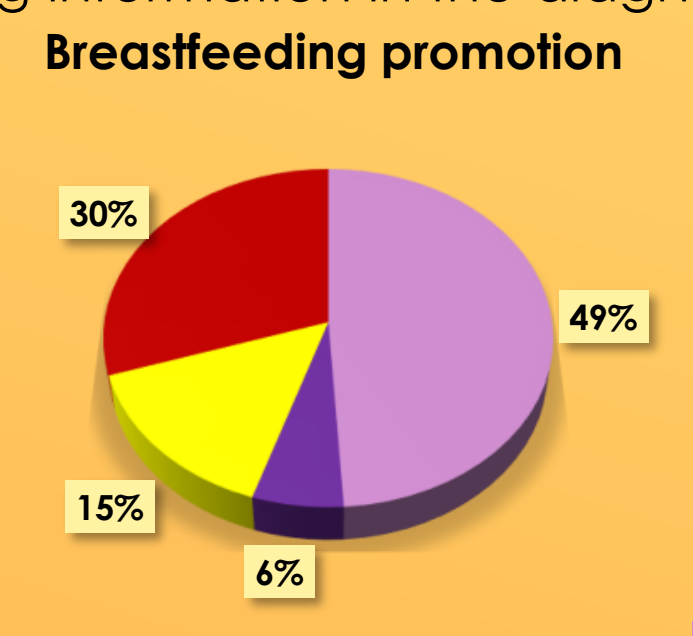

Access to a Human Bank Milk

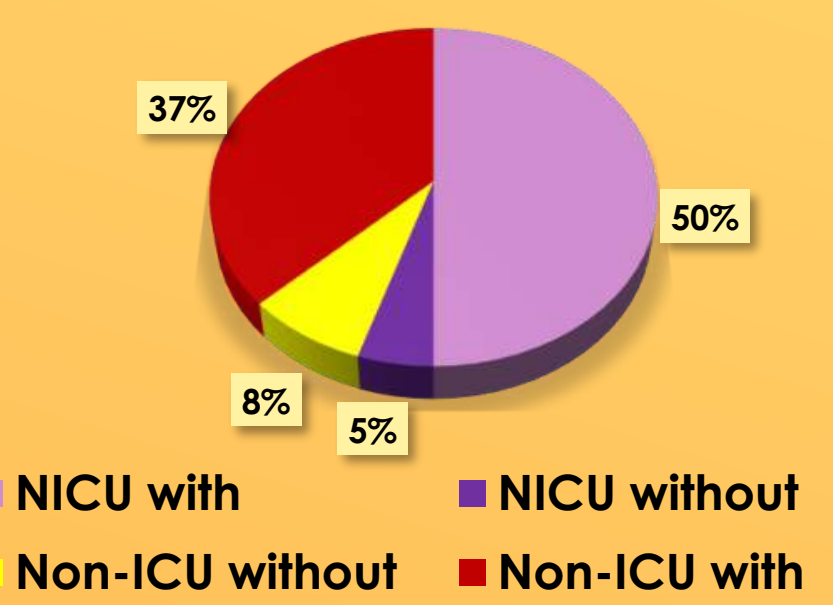

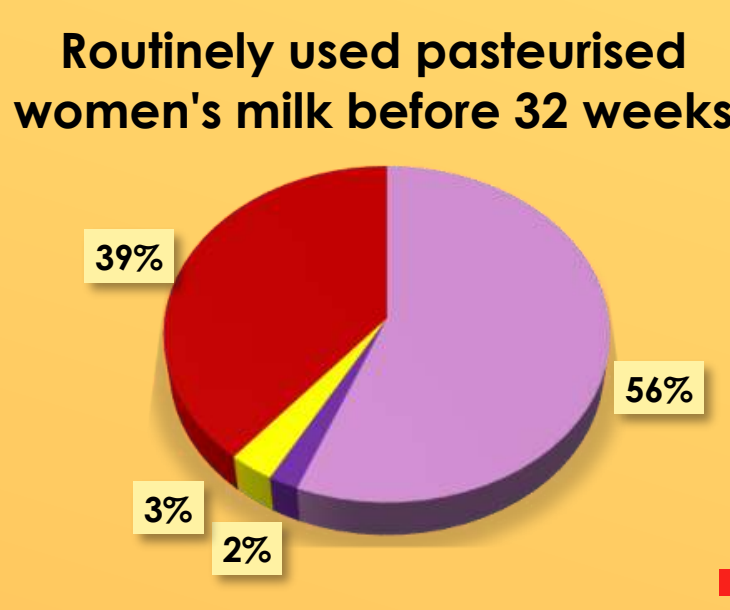

Main barrier to the use of raw breast milk

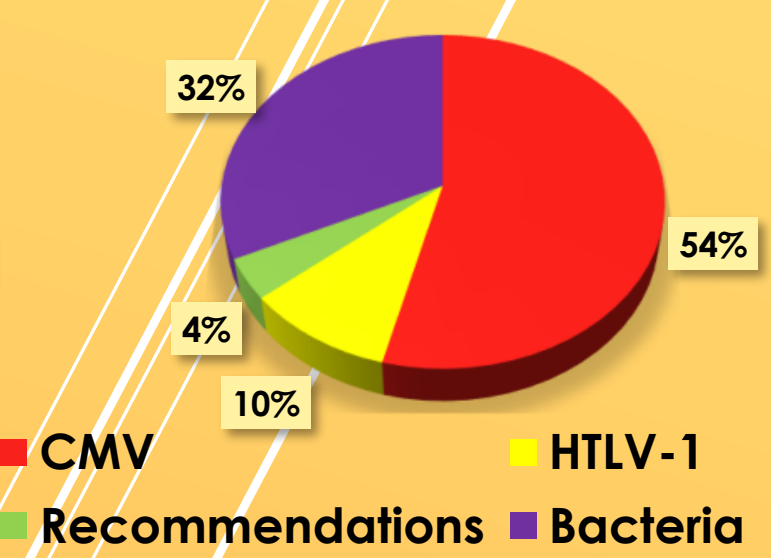

Summary of the current use of raw breast milk in France

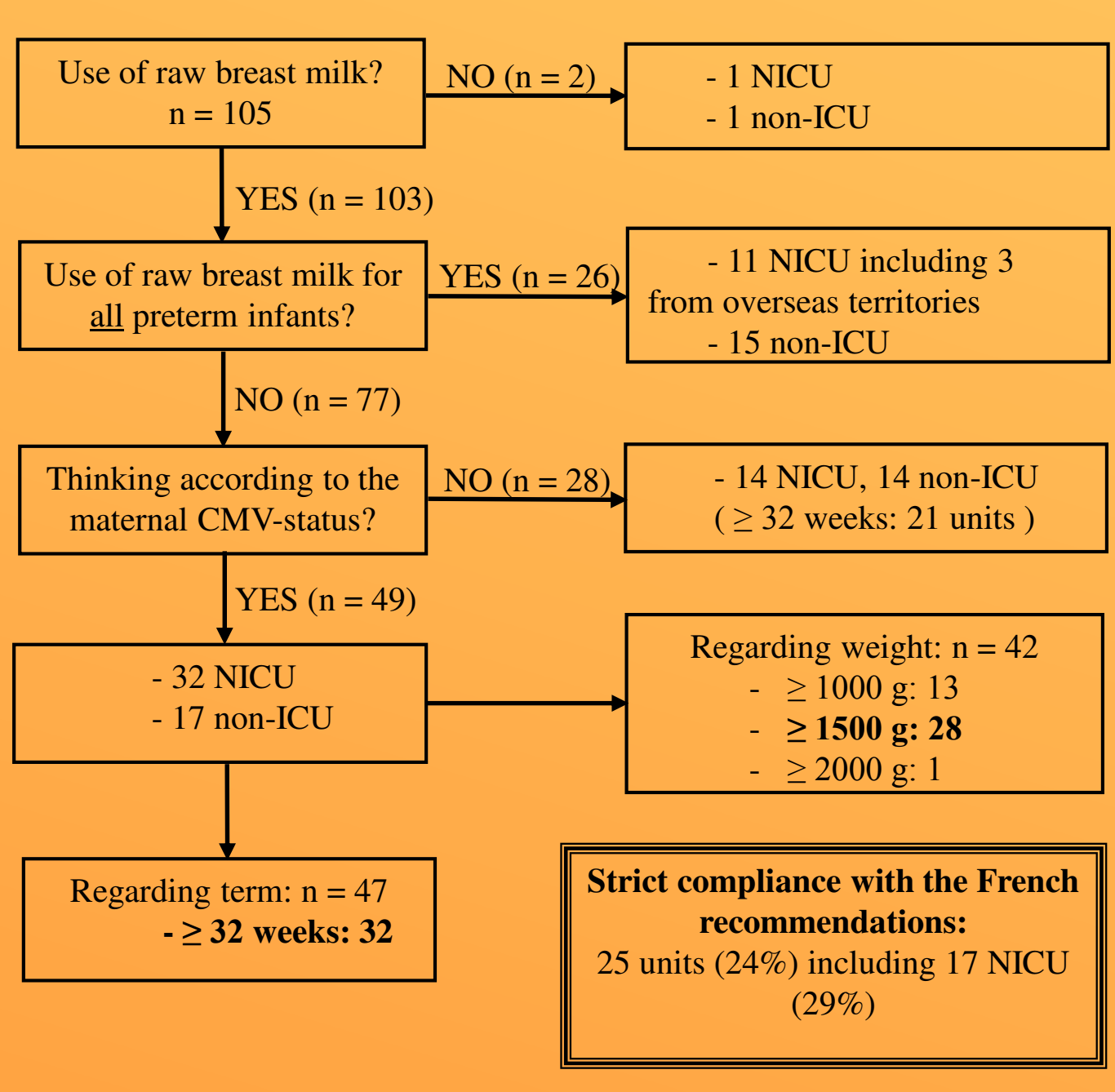

\begin{tabular}{|c|c|c|c|c|}
\hline $\begin{array}{l}\text { "Proven" } \\
\text { infections }\end{array}$ & Term at birth & $\begin{array}{l}\text { Weight at } \\
\text { birth }\end{array}$ & $\begin{array}{l}\text { Age } \\
\text { (day) }\end{array}$ & Symptoms \\
\hline 1 & 27 weeks 4 days & $550 \mathrm{~g}$ & 50 & $\begin{array}{c}\text { "Sepsis-like", NEC, } \\
\text { death }\end{array}$ \\
\hline 2 & 27 weeks 4 days & $1000 \mathrm{~g}$ & 50 & Asymptomatic \\
\hline 3 & 26 weeks & $810 \mathrm{~g}$ & 70 & "Sepsis-like", NEC \\
\hline 4 & 27 weeks & $900 \mathrm{~g}$ & 60 & "Sepsis-like", NEC \\
\hline 5 & 29 weeks & $1200 \mathrm{~g}$ & 53 & Asymptomatic \\
\hline \multicolumn{5}{|c|}{ "Highly probable" infections } \\
\hline 6 & 25 weeks 5 days & $900 \mathrm{~g}$ & 36 & $\begin{array}{l}\text { Thrombocytopeni } \\
\text { ahyperleukocytosi } \\
\mathrm{s}\end{array}$ \\
\hline 7 & 27 weeks & I & 30 & "Sepsis-like" \\
\hline 8 & 27 weeks 5 days & $950 \mathrm{~g}$ & 41 & $\begin{array}{l}\text { "Sepsis-like", } \\
\text { thrombocytopeni } \\
\text { a NEC, death }\end{array}$ \\
\hline 9 & 28 weeks & $1125 \mathrm{~g}$ & 60 & $\begin{array}{c}\text { Thrombocytopeni } \\
\text { a }\end{array}$ \\
\hline 10 & 30 weeks & $1500 \mathrm{~g}$ & $\begin{array}{c}15 \text { and } \\
40\end{array}$ & $\begin{array}{l}\text { Cholestasis } \\
\text { "Sepsis-like" }\end{array}$ \\
\hline 11 & 33 weeks & $>2000 \mathrm{~g}$ & 20 & "Sepsis-like", NEC \\
\hline 12 & 33 weeks & $>2000 \mathrm{~g}$ & 20 & Adenopathies \\
\hline \multicolumn{5}{|c|}{ "Probable" infections } \\
\hline 13 & 25 weeks & $570 \mathrm{~g}$ & 90 & $\begin{array}{l}\text { Unconfirmed } \\
\text { hearing loss }\end{array}$ \\
\hline 14 & 32 weeks & $>2000$ & 35 & "Sepsis-like" \\
\hline 15 & 32 weeks & 1950 & 60 & $\begin{array}{c}\text { Severe } \\
\text { leukopenia }\end{array}$ \\
\hline
\end{tabular}

Characteristics of CMV Breast milk-acquired infections

Conclusion: Due to a high rate of participation, this work offers a global vision of clinical practices in France. Thus, a high heterogeneity marks medical practices concerning the use of raw breast milk and the diagnostic approach for breast milkacquired CMV infection is often incomplete with an important reporting bias. In this context, new recommendations seem challenging to formulate. The establishment of a structured diagnostic approach should be an effective way to assess the real infectious risk, identify a population at risk and, then, write new recommendations.

References: 1. Hamprecht, K. et al. Lancet 2001. 2. Vochem, M. et al. Pediatr. Infect. Dis. J. 1998. 3. Section on Breastfeeding Breastfeeding and the Use of Human Milk. PEDIATRICS 2005. 4. Omarsdottir, S. et

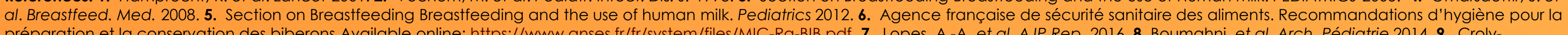
préparation et la conservation des biberons Available online: https://www.anses.fr/fr/system/files/MIC-Ra-BIB.pdf. 7. Lopes, A.-A, et al. AJP Rep. 2016. 8. Boumahni, et al. Arch. Pédiatrie 2014. 9. Croly- 